\title{
Basis for a Choice of a Political Party as a Cause for Political Preferences of Students
}

\author{
Mikhail Basimov \\ Doctor of psychological sciences, associate professor \\ Department of labour psychology and special psychology \\ Russian State Social University (RSSU) \\ Moscow, Russia \\ basimov_@mail.ru \\ Vasilyi Kornienko \\ Ph.D. of philosophy \\ associate professor of Humanitarian Institute \\ Kurgan State University (KSU) \\ Kurgan, Russia \\ kornienko45@mail.ru
}

\begin{abstract}
The article deals with the statistical dependence of interval variables-estimates (attitudes to voting results, satisfaction with the work of state bodies, the respondents' attitudes to political parties, political leaders and other parameters) on the nominal parameter "Basis for Choice of a Political Party", which is represented by 9 nominal responses, characterized the respondent's attitude to the political organization. There are also 13 dependent (interval) parameters, characterized respondents' interest in politics, estimations of the work of political and state leaders, attitude to the various significant political events in Russia and others analyzed with a new version of the authorial method. The method applied to analyze cause and effect relation in parallel for any interval and nominal variables, and as a result, it became possible to speak about the dependence of an interval parameter on a multivalued nominal variable, and to select the relation necessary in strength, based only on numerical values.
\end{abstract}

Keywords - social preferences and orientations, political preferences and orientations, interval and nominal variables, cause-effect relations.

\section{INTRODUCTION}

The article deals with the dependence of interval variables-estimates (attitudes to voting results, satisfaction with the work of state bodies, the respondents' attitudes to political parties, political leaders and other parameters) on the nominal parameter "Basis for Choice of a Party".

It is represented by nine nominal responses:

1. I like its leader.

2. It has a reliable team.

3. I like its program.
4. It knows best what to do.

5. It has clear goals.

6. No more worthy, no one else to vote for.

7. Is in opposition to the current government.

8. Just decided.

9. Did not vote.

We list the dependent (interval) parameters:

1. Interest in politics.

2. Attitude towards the LDPR party.

3. Attitudes to the Communist party.

4. Attitude towards the Yabloko party.

5. Attitude to V.V. Putin.

6. Attitude to D. A. Medvedev.

7. Attitude to V.V. Zhirinovsky.

8. Attitude to M.D. Prokhorov.

9. Attitude to S.M. Mironov.

10. Attitude to A.A. Navalny.

11. Dissatisfaction with the results of voting in the elections to the RF State Duma.

12. A satisfaction with the results of voting in the Russian Federation presidential elections.

13. Satisfied with the work of the Russian President V.V. Putin.

14. Subjective assessment of their financial situation. 
A new version of authorial method applied to analyze cause and effect dependence in parallel for any interval and nominal variables, and "as a result, it became possible to speak about the dependence of an interval parameter on a multivalued nominal variable, and to select the relation necessary in strength, based only on numerical values" [3]

"When we combine any quantile partitions by interval parameters and groups by nominal responses into one multiple comparison problem, we obtain a result for nominal and interval parameters on a single scale of comparative weightiness. Then, they (triads or quarts) allow us to construct the strength of relation coefficients according to interval parameters, as before, and normalize them to a single analog correlation (dependency of interval parameter upon itself). The relation coefficients analogues must be similarly normalized for the groups according to nominal responses. Note that in the case of nominal variables, we can discuss the dependence only in one direction: like the interval parameters depend on the nominal parameters." [3]

Thus, it became possible to talk about the dependence of the interval parameter on the multivalued nominal variable and to select the relation necessary in strength, based on numerical values only" [3]

"When constructing the strength of relation coefficients (after a general problem of multiple comparisons for all parameters) we suggest two strategies:

1. We should take two nominal responses corresponding to maximum and minimum values of the comparative weightiness of the interval parameter, whose dependence on the nominal parameter is determined.

2. We should take (a search of all variants) three (in the case of triads for interval parameters) or four (in the case of quarts) nominal responses each time. Then the relation coefficient analogues for three (four) nominal responses are determined, after which the relation coefficients become averaged over all permutations, since the nominal responses are equal to each other and the streamlining of operation is not implemented for them." [3].

'The first strategy is obviously the more stringent and determines a fewer number of relation as strong ones" [3].

We will consider the issue of how the second strategy has identified strong relation in the case where the cause is a nominal variable of "Basis for Choice of a Party".

\section{RESULTS}

A sociological study of a "civil marriage" phenomenon and a problem of its image formation influenced by students' political orientations was conducted as a part of sociological laboratory work plan (2014). 24 quantitative parameters were selected or constructed to examine the dependence (linear and nonlinear)
The independent (nominal) parameter "Basis for Choice of a Party" is a choice from nine responses proposed:

1. I like its leader (G18-01).

2. It has a reliable team (G18-02).

3. I like its program (G18-03).

4. It knows best what to do (G18-04).

5. It has clear goals (G18-05).

6. No more worthy, no one else to vote for (G18-06).

7. Is in opposition to the current government (G18-07).

8. Just decided (G18-08).

9. Did not vote (G18-09).

Let us consider the dependence of 14 interval (quantitative) variables on the nominal variable "Basis for Choice of a Party", which takes 9 values.

TABLE I. DEPENDENCE OF THE INTERVAL PARAMETER (VARIABLE) "INTEREST IN POLITICS" (X05) FROM THE NOMINAL PARAMETER (VARIABLE) "BASIS FOR CHOICE OF A PARTY" (G18)

\begin{tabular}{|c|c|c|}
\hline $\begin{array}{c}\text { Response } \\
\text { group }\end{array}$ & $\begin{array}{c}\text { Comparative } \\
\text { weightiness }\end{array}$ & $\begin{array}{c}\text { Nominal answer to the } \\
\text { question-cause } \\
\text { "average permutations" } \\
\text { relation }\end{array}$ \\
\hline G18-01 & -247 & I like its le \\
\hline G18-02 & $+\mathbf{1 8 8 2}$ & It has a reliable team \\
\hline G18-05 & $\mathbf{+ 1 1 2 0}$ & It has clear goals \\
\hline G18-08 & $-\mathbf{1 1 7 3}$ & Just decided \\
\hline \multicolumn{3}{|c|}{$\begin{array}{c}\text { Factor of the connection strength } \\
\text { (average of the 24 permutations) }=0.59\end{array}$} \\
\hline \multicolumn{3}{|c|}{$\begin{array}{c}\text { Factor of the connection strength } \\
\text { (maximum value) }=0.84\end{array}$} \\
(1243)
\end{tabular}

The interval parameter "Interest in politics" can be considered as a kind of indicator for the survey results reliability, since the greatest comparative weightiness are observed for nominal responses corresponding to the real understanding or misunderstanding of political processes: the party (which I choose) has a reliable team (comparative weightiness $=+1882)$. The response: "Just decided" $(-1173)$ testifies to a minimal interest in policy. 
TABLE II. DEPENDENCE OF THE INTERVAL PARAMETER (VARIABLE) “ATTITUDE TOWARDS THE LDPR PARTY" (X09) FROM THE NOMINAL PARAMETER (VARIABLE) "BASIS FOR CHOICE OF A PARTY" (G18)

\begin{tabular}{|c|c|c|}
\hline $\begin{array}{c}\text { Response } \\
\text { group }\end{array}$ & $\begin{array}{c}\text { Comparative } \\
\text { weightiness }\end{array}$ & $\begin{array}{c}\text { Nominal answer to the } \\
\text { question-cause } \\
\text { Strategy of identifying the } \\
\text { "average permutations" } \\
\text { relation }\end{array}$ \\
\hline $\mathbf{G 1 8 - 0 1}$ & $\mathbf{+ 3 7 8 9}$ & I like its le \\
\hline $\mathbf{G 1 8 - 0 4}$ & $\mathbf{+ 3 4 8 3}$ & It knows best what to do \\
\hline $\mathbf{G 1 8 - 0 8}$ & $\mathbf{- 2 3 3}$ & Just decided \\
\hline $\mathbf{G 1 8 - 0 9}$ & $\mathbf{- 1 0 9 5}$ & Did not vote \\
\hline \multicolumn{3}{|c|}{$\begin{array}{c}\text { Factor of the connection strength } \\
\text { (average of the 24 permutations) }=1.04\end{array}$} \\
\hline
\end{tabular}

Those respondents who explained the basis when choosing the party as "I like its leader" $(+3789)$ or "It knows better than others what to do" $(+3483)$ had positive attitudes towards LDPR is present in.

TABLE III. DEPENDENCE OF THE INTERVAL PARAMETER (VARIABLE) “ATTITUDES TO THE COMMUNIST PARTY" (X10 ) FROM THE NOMINAL PARAMETER (VARIABLE) "BASIS FOR CHOICE OF A PARTY" (G18)

\begin{tabular}{|c|c|c|}
\hline $\begin{array}{c}\text { Response } \\
\text { group }\end{array}$ & $\begin{array}{c}\text { Comparative } \\
\text { weightiness }\end{array}$ & $\begin{array}{c}\text { Nominal answer to the } \\
\text { question-cause } \\
\text { Strategy of identifying the } \\
\text { "average permutations" } \\
\text { relation }\end{array}$ \\
\hline $\mathbf{G 1 8 - 0 2}$ & $-\mathbf{6 4 5}$ & It has a reliable team \\
\hline $\mathbf{G 1 8 - 0 3}$ & $+\mathbf{1 9 1 1}$ & I like its program \\
\hline $\mathbf{G 1 8 - 0 7}$ & +3666 & $\begin{array}{c}\text { Is in opposition to the current } \\
\text { government }\end{array}$ \\
\hline $\mathbf{G 1 8 - 0 9}$ & $-\mathbf{5 8 7}$ & Did not vote \\
\hline \multicolumn{3}{|c|}{$\begin{array}{c}\text { Factor of the connection strength } \\
\text { (average of the } 24 \text { permutations) }=0.87\end{array}$} \\
\hline \multicolumn{3}{|c|}{$\begin{array}{c}\text { Factor of the connection strength } \\
\text { (maximum value) }=1.26 \quad(2134)\end{array}$} \\
\hline
\end{tabular}

The respondents who choose a party based on its opposition to the current government had positive attitudes to the Communist party $(+3666)$.

TABLE IV. DEPENDENCE OF THE INTERVAL PARAMETER

(VARIABLE) "ATTITUDE TOWARDS THE YABLOKO PARTY" (X11) FROM THE NOMINAL PARAMETER (VARIABLE) "BASIS FOR

\begin{tabular}{|c|c|c|}
\hline $\begin{array}{l}\text { Response } \\
\text { group }\end{array}$ & $\begin{array}{l}\text { Comparative } \\
\text { weightiness }\end{array}$ & $\begin{array}{c}\text { Nominal answer to the } \\
\text { question-cause } \\
\text { Strategy of identifying the } \\
\text { "average permutations" } \\
\text { relation }\end{array}$ \\
\hline G18-03 & -551 & I like its program \\
\hline G18-04 & +1331 & It knows best what to do \\
\hline G18-07 & -3407 & $\begin{array}{l}\text { Is in opposition to the current } \\
\text { government }\end{array}$ \\
\hline G18-08 & +516 & Just decided \\
\hline \multicolumn{3}{|c|}{$\begin{array}{l}\text { Factor of the connection strength } \\
\text { (average of the } 24 \text { permutations) }=0.86\end{array}$} \\
\hline \multicolumn{3}{|c|}{$\begin{array}{l}\text { Factor of the connection strength } \\
\text { (maximum value) }=1.19 \quad(1234)\end{array}$} \\
\hline
\end{tabular}

The respondents who choose a party based on its opposition to the current government had negative attitudes towards the party of Yabloko (-3407).

TABLE V. DEPENDENCE OF THE INTERVAL PARAMETER

(VARIABLE) "ATTITUDE TO V.V. PUTIN" (X12) FROM THE NOMINAL PARAMETER (VARIABLE) "BASIS FOR CHOICE OF A PARTY" (G18)

\begin{tabular}{|c|c|c|}
\hline $\begin{array}{c}\text { Response } \\
\text { group }\end{array}$ & $\begin{array}{c}\text { Comparative } \\
\text { weightiness }\end{array}$ & $\begin{array}{c}\text { Nominal answer to the } \\
\text { question-cause } \\
\text { Strategy of identifying the } \\
\text { "average permutations" } \\
\text { relation }\end{array}$ \\
\hline $\mathbf{G 1 8 - 0 2}$ & $+\mathbf{1 1 2 2}$ & It has a reliable team \\
\hline $\mathbf{G 1 8 - 0 3}$ & -441 & I like its program \\
\hline $\mathbf{G 1 8 - 0 4}$ & $+\mathbf{2 1 5 7}$ & It knows best what to do \\
\hline $\mathbf{G 1 8 - 0 9}$ & $-\mathbf{5 3 5}$ & Did not vote \\
\hline \multicolumn{3}{|c|}{$\begin{array}{c}\text { Factor of the connection strength } \\
\text { (average of the } 24 \text { permutations) }=0.54\end{array}$} \\
\multicolumn{3}{|c|}{$\begin{array}{c}\text { Factor of the connection strength } \\
\text { (maximum value) }=0.78 \quad(1432)\end{array}$} \\
\hline
\end{tabular}

A positive attitude to V.V. Putin (+2157) is typical for a group of respondents, who choose a party based on their opinion that it knows better than others what to do.

TABLE VI. DEPENDENCE OF THE INTERVAL PARAMETER (VARIABLE) “ATTITUDE TO D. A. MEDVEDEV” (X13) FROM THE NOMINAL PARAMETER (VARIABLE) "BASIS FOR CHOICE OF A PARTY" (G18)

\begin{tabular}{|c|c|c|}
\hline $\begin{array}{c}\text { Response } \\
\text { group }\end{array}$ & $\begin{array}{c}\text { Comparative } \\
\text { weightiness }\end{array}$ & $\begin{array}{c}\text { Nominal answer to the } \\
\text { question-cause } \\
\text { Strategy of identifying the } \\
\text { "average permutations" } \\
\text { relation }\end{array}$ \\
\hline G18-01 & +633 & I like its le \\
\hline G18-04 & +2828 & It knows best what to do \\
\hline G18-07 & -263 & $\begin{array}{c}\text { Is in opposition to the current } \\
\text { government }\end{array}$ \\
\hline G18-09 & -510 & Did not vote \\
\hline \multicolumn{3}{|c|}{$\begin{array}{c}\text { Factor of the connection strength } \\
\text { (average of the 24 permutations) }=0.62\end{array}$} \\
\hline \multicolumn{3}{|c|}{$\begin{array}{c}\text { Factor of the connection strength } \\
\text { (maximum value) }=0.86\end{array}$} \\
\hline
\end{tabular}

Similarly, a positive attitude to D. A. Medvedev (+2828) is typical for a group of respondents, who choose a party based on their opinion that it knows better than others what to do. 
TABLE VII. DEPENDENCE OF THE INTERVAL PARAMETER (VARIABLE) "ATTITUDE TO V.V. ZHIRINOVSKY" (X14) FROM THE NOMINAL PARAMETER (VARIABLE) "BASIS FOR CHOICE OF A PARTY" (G18)

\begin{tabular}{|c|c|c|}
\hline $\begin{array}{c}\text { Response } \\
\text { group }\end{array}$ & $\begin{array}{c}\text { Nominal answer to the } \\
\text { question-cause } \\
\text { weightiness } \\
\text { Strategy of identifying the } \\
\text { "average permutations" } \\
\text { relation }\end{array}$ \\
\hline $\mathbf{G 1 8 - 0 2}$ & -162 & It has a reliable team \\
\hline $\mathbf{G 1 8 - 0 3}$ & $+\mathbf{1 8 3 9}$ & I like its program \\
\hline $\mathbf{G 1 8 - 0 7}$ & $+\mathbf{3 9 3 7}$ & $\begin{array}{c}\text { Is in opposition to the } \\
\text { current government }\end{array}$ \\
\hline $\mathbf{G 1 8 - 0 9}$ & $-\mathbf{1 2 0 1}$ & Did not vote \\
\hline \multicolumn{3}{|c|}{$\begin{array}{c}\text { Factor of the connection strength } \\
\text { (average of the 24 permutations) }=0.98\end{array}$} \\
\hline
\end{tabular}

The respondents who choose a party based on its opposition to the current government had apparently positive attitudes to V.V. Zhirinovsky (+3937).

TABLE VIII. DEPENDENCE OF THE INTERVAL PARAMETER (VARIABLE) "ATTITUDE TO M.D. PROKHOROV" (X16) FROM THE NOMINAL PARAMETER (VARIABLE) "BASIS FOR CHOICE OF A PARTY" (G18)

\begin{tabular}{|c|c|c|}
\hline $\begin{array}{l}\text { Response } \\
\text { group }\end{array}$ & $\begin{array}{l}\text { Comparative } \\
\text { weightiness }\end{array}$ & $\begin{array}{c}\text { Nominal answer to the } \\
\text { question-cause } \\
\text { Strategy of identifying the } \\
\text { "average permutations" } \\
\text { relation }\end{array}$ \\
\hline G18-05 & -2301 & It has clear goals \\
\hline G18-06 & -833 & $\begin{array}{c}\text { No more worthy, no one else } \\
\text { to vote for }\end{array}$ \\
\hline G18-08 & +2020 & Just decided \\
\hline G18-09 & +1277 & Did not vote \\
\hline \multicolumn{3}{|c|}{$\begin{array}{c}\text { Factor of the connection strength } \\
\text { (average of the } 24 \text { permutations) }=0.85\end{array}$} \\
\hline \multicolumn{3}{|c|}{$\begin{array}{l}\text { Factor of the connection strength } \\
\text { (maximum value) }=1.21 \quad \text { (2314) }\end{array}$} \\
\hline
\end{tabular}

The group of respondents whose basis for choosing a party is the following motto "Just decided" had positive attitudes (+2020) to M.D. Prokhorov. However, the negative attitude (-2301) to M.D. Prokhorov is observed in the group, whose members choose the following response when choosing a party that "It has clear goals".
TABLE IX. DEPENDENCE OF THE INTERVAL PARAMETER (VARIABLE) “ATTITUDE TO S.M. MIRONOV” (X17) FROM THE NOMINAL PARAMETER (VARIABLE) "BASIS FOR CHOICE OF A PARTY" (G18)

\begin{tabular}{|c|c|c|}
\hline $\begin{array}{l}\text { Response } \\
\text { group }\end{array}$ & $\begin{array}{l}\text { Comparative } \\
\text { weightiness }\end{array}$ & $\begin{array}{l}\text { Nominal answer to the } \\
\text { question-cause } \\
\text { Strategy of identifying the } \\
\text { "average permutations" } \\
\text { relation }\end{array}$ \\
\hline G18-02 & -1163 & It has a reliable team \\
\hline G18-06 & -514 & $\begin{array}{c}\text { No more worthy, no one else } \\
\text { to vote for }\end{array}$ \\
\hline G18-07 & +88 & $\begin{array}{c}\text { Is in opposition to the current } \\
\text { government }\end{array}$ \\
\hline G18-08 & +2418 & Just decided \\
\hline \multicolumn{3}{|c|}{$\begin{array}{l}\text { Factor of the connection strength } \\
\text { (average of the } 24 \text { permutations) }=0.64\end{array}$} \\
\hline \multicolumn{3}{|c|}{$\begin{array}{l}\text { Factor of the connection strength } \\
\text { (maximum value) }=0.88 \quad(2413)\end{array}$} \\
\hline
\end{tabular}

The group of respondents whose basis for choosing a party is the following motto "Just decided" had positive attitudes $(+2418)$ towards S.M. Mironov.

TABLE $X . \quad$ DEPENDENCE OF THE INTERVAL PARAMETER (VARIABLE) “ATTITUDE TO A.A. NAVALNY” (X18) FROM THE NOMINAL PARAMETER (VARIABLE) "BASIS FOR CHOICE OF A PARTY" (G18)

\begin{tabular}{|c|c|c|}
\hline $\begin{array}{c}\text { Response } \\
\text { group }\end{array}$ & $\begin{array}{c}\text { Comparative } \\
\text { weightiness }\end{array}$ & $\begin{array}{c}\text { Nominal answer to the } \\
\text { question-cause } \\
\text { Strategy of identifying the } \\
\text { "average permutations" } \\
\text { relation }\end{array}$ \\
\hline $\mathbf{G 1 8 - 0 2}$ & $-\mathbf{2 0 6 2}$ & It has a reliable team \\
\hline $\mathbf{G 1 8 - 0 4}$ & $-\mathbf{- 1 6 6 5}$ & It knows best what to do \\
\hline $\mathbf{G 1 8 - 0 8}$ & $\mathbf{+ 6 8 4}$ & Just decided \\
\hline $\mathbf{G 1 8 - 0 9}$ & $+\mathbf{1 5 9}$ & Did not vote \\
\hline \multicolumn{3}{|c|}{$\begin{array}{c}\text { Factor of the connection strength } \\
\text { (average of the 24 permutations) }=0.57\end{array}$} \\
\hline \multicolumn{3}{|c|}{$\begin{array}{c}\text { Factor of the connection strength } \\
\text { (maximum value) }=0.83\end{array}$} \\
(2314)
\end{tabular}

The group of respondents who choose a party because a party has a reliable team had negative attitudes $(-2062)$ to A.A. Navalny. 
TABLE XI. DEPENDENCE OF THE INTERVAL PARAMETER (VARIABLE) "DISSATISFACTION WITH THE RESULTS OF VOTING IN THE ELECTIONS TO THE RF STATE DUMA” (X19) FROM THE NOMINAL PARAMETER (VARIABLE) "BASIS FOR CHOICE OF A PARTY" (G18)

\begin{tabular}{|c|c|c|}
\hline $\begin{array}{c}\text { Response } \\
\text { group }\end{array}$ & $\begin{array}{c}\text { Comparative } \\
\text { weightiness }\end{array}$ & $\begin{array}{c}\text { Nominal answer to the } \\
\text { question-cause } \\
\text { Strategy of identifying the } \\
\text { "average permutations" } \\
\text { relation }\end{array}$ \\
\hline G18-02 & +539 & It has a reliable team \\
\hline G18-03 & -698 & I like its program \\
\hline G18-04 & +876 & It knows best what to do \\
\hline G18-07 & -3291 & $\begin{array}{c}\text { Is in opposition to the current } \\
\text { government }\end{array}$ \\
\hline \multicolumn{3}{|c|}{$\begin{array}{c}\text { Factor of the connection strength } \\
\text { (average of the 24 permutations) }=0.78\end{array}$} \\
\multicolumn{3}{|c|}{$\begin{array}{c}\text { Factor of the connection strength } \\
\text { (maximum value) }=1.08 \quad 1432)\end{array}$} \\
\hline
\end{tabular}

The negative attitude to the voting results at the elections to the Russian Federation State Duma (-3291) is present in the respondents, who choose a party based on its opposition to the current government.

TABLE XII. DEPENDENCE OF THE INTERVAL PARAMETER (VARIABLE) "A SATISFACTION WITH THE RESULTS OF VOTING

IN THE RUSSIAN FEDERATION PRESIDENTIAL ELECTIONS" (X20) FROM THE NOMINAL PARAMETER (VARIABLE) "BASIS FOR CHOICE OF A PARTY" (G18)

\begin{tabular}{|c|c|c|}
\hline $\begin{array}{l}\text { Response } \\
\text { group }\end{array}$ & $\begin{array}{l}\text { Comparative } \\
\text { weightiness }\end{array}$ & $\begin{array}{l}\text { Nominal answer to the } \\
\text { question-cause } \\
\text { Strategy of identifying the } \\
\text { "average permutations" } \\
\text { relation }\end{array}$ \\
\hline G18-02 & +1208 & It has a reliable team \\
\hline G18-03 & -593 & I like its program \\
\hline G18-04 & +477 & It knows best what to do \\
\hline G18-07 & -3768 & $\begin{array}{l}\text { Is in opposition to the current } \\
\text { government }\end{array}$ \\
\hline \multicolumn{3}{|c|}{$\begin{array}{l}\text { Factor of the connection strength } \\
\text { (average of the } 24 \text { permutations) }=0.90\end{array}$} \\
\hline \multicolumn{3}{|c|}{$\begin{array}{l}\text { Factor of the connection strength } \\
\text { (maximum value) }=1.25 \quad(2143)\end{array}$} \\
\hline
\end{tabular}

Similarly, the respondents who choose a party based on its opposition to the current government had negative attitudes to the voting results at the Russian Federation presidential elections $(-3768)$.
TABLE XIII. DEPENDENCE OF THE INTERVAL PARAMETER (VARIABLE) "SATISFIED WITH THE WORK OF THE RUSSIAN PRESIDENT V.V. PUTIN" (X21) FROM THE NOMINAL PARAMETER (VARIABLE) "BASIS FOR CHOICE OF A PARTY" (G18)

\begin{tabular}{|c|c|c|}
\hline $\begin{array}{l}\text { Response } \\
\text { group }\end{array}$ & $\begin{array}{l}\text { Comparative } \\
\text { weightiness }\end{array}$ & $\begin{array}{l}\text { Nominal answer to the } \\
\text { question-cause } \\
\text { Strategy of identifying the } \\
\text { "average permutations" } \\
\text { relation }\end{array}$ \\
\hline G18-02 & +512 & It has a reliable team \\
\hline G18-03 & -365 & I like its program \\
\hline G18-04 & +1288 & It knows best what to do \\
\hline G18-07 & -1602 & $\begin{array}{l}\text { Is in opposition to the current } \\
\text { government }\end{array}$ \\
\hline \multicolumn{3}{|c|}{$\begin{array}{l}\text { Factor of the connection strength } \\
\text { (average of the } 24 \text { permutations) }=0.54\end{array}$} \\
\hline \multicolumn{3}{|c|}{$\begin{array}{l}\text { Factor of the connection strength } \\
(\text { maximum value })=0.75 \quad(1432)\end{array}$} \\
\hline
\end{tabular}

However, the satisfaction with the work of Russian President Vladimir Putin identified two opposing groups: a group with positive attitudes $(+1288)$ who choose a party because it knows better than others do what to do; and a group with negative attitudes (-1602), who choose a party based on its opposition to the current government.

TABLE XIV. DEPENDENCE OF THE INTERVAL PARAMETER (VARIABLE) "SUBJECTIVE ASSESSMENT OF THEIR FINANCIAI SITUATION" (X24) FROM THE NOMINAL PARAMETER (VARIABLE) "BASIS FOR CHOICE OF A PARTY" (G18)

\begin{tabular}{|c|c|c|}
\hline $\begin{array}{c}\text { Response } \\
\text { group }\end{array}$ & $\begin{array}{c}\text { Comparative } \\
\text { weightiness }\end{array}$ & $\begin{array}{c}\text { Nominal answer to the } \\
\text { question-cause } \\
\text { Strategy of identifying the } \\
\text { "average permutations" } \\
\text { relation }\end{array}$ \\
\hline G18-02 & +1544 & It has a reliable team \\
\hline G18-03 & -577 & I like its program \\
\hline G18-04 & +2088 & It knows best what to do \\
\hline G18-05 & -463 & It has clear goals \\
\hline \multicolumn{3}{|c|}{$\begin{array}{c}\text { Factor of the connection strength } \\
\text { (average of the } 24 \text { permutations) }=0.56\end{array}$} \\
\multicolumn{3}{|c|}{$\begin{array}{c}\text { Factor of the connection strength } \\
\text { (maximum value) }=0.83 \\
\text { (1234) }\end{array}$} \\
\hline
\end{tabular}

The subjective assessment of their financial situation is quite high (+2088) among the respondents, who choose a party because it knows better than others do what to do.

\section{CONCLUSION}

We demonstrated the new method for joint analysis of interval and multivalued nominal data on the specific study data in the context of political sociology. As a result, we obtain the new cause and effect information, as the interval variables depend on multivalued nominal variables.

This continues research in the context of nonlinear nature with regard to social sciences (human sciences): 
1. Author's method of multiple comparison.

2. Author's method of studying statistical relations $[1,2]$.

3. Nonlinearity of psychological and social science $[3,4$, $5,7,8,12,13,14,15]$.

4. Synergetic paradigms in the science $[6,9,10,11]$.

5. International and European Congresses of Psychology and Sociology: ICP, ISA, ECP, ESA (58 prezentations).

It also staticizes acceptance synergetic paradigms in psychological and social science.

At the same time, the nonlinear nature of psychological and sociological data is not relevant for most researchers, although the nonlinearity of psychological and social has already been revealed in numerous studies with the help of the authorial method.

\section{Acknowledgments}

Preparation of the paper was supported by grant of the Russian Foundation for Basic Research (RFBR). Project № 18-011-01071a.

\section{References}

[1] Basimov M. "Convenient" correlational errors in modern psychological science (mathematical aspect). The European Proceedings of Social \& Behavioural Sciences EpSBS, vol. L, Published by the Future Academy, pp. 137-146, 2018.

[2] Basimov M. The analysis of statistical dependences in non-linear psychology.Int. J. of Psychology, Vol. 51, Supplement S1, pp. 851, 2016.
[3] Basimov M. Political activity as a cause for political and social preferences of students. Advances in Social Science, Education and Humanities Research, Vol. 289, pp. 495-499, 2018.

[4] Basimova P. Competitiveness as the reason Impulsiveness in non-linear psychology (Five-Factor Personality Model). International Journal of Psychology, Vol. 51, Supplement S1, pp. 903, 2016.

[5] Basimova P. Commitment to Principles in Pedagogic Activity (non-linear aspect). International Journal of Psychology, Vol. 51, Supplement S1, pp. 789, 2016.

[6] DanilovYu.V. Nonlinearity. Introduction to Synergetics. http://spkurdyumov.ru/category/ introduction, 2016.

[7] Ilinyh Y. Non-linear influence of severity on the lifemean orientations of the child. International Journal of Psychology, Vol. 47, Supplement 1, pp. 261, 2012.

[8] Ilinyh Y. Non-linear effects in interaction "child-parent". International Journal of Psychology, Vol. 47, Supplement 1, pp. 261, 2012.

[9] Knjazeva E.N., Kurdyumov S.P. Bas of synergetrics. Synergetic Worldseeing. Moscow: KomKniga, 2005.

[10] Krylov V.Yu. Methodological and idealized problems of mathematical psychology. Moscow: Yanus-K., 2000.

[11] Mainzer K. Thinking in Complexity. The Complex Dynamics of Matter, Mind, and Mankind. Berlin: Springer-Verlag, 1994.

[12] Nikolaeva I. Value characteristic "I" as object of non-linear psychology. The $14^{\text {th }}$ European Congress of Psychology (Milan, Italy 710 july 2015), AbstractBook, Posters, pp. 784, 2015.

[13] Nikolaeva I. Non-linear relation of durability and subjective remoteness from "Worst others". The $14^{\text {th }}$ European Congress of Psychology (Milan, Italy 7-10 july 2015), AbstractBook, Posters, pp. 785, 2015.

[14] Padurina E. Non-linear influence of the gnostic emotional orientations on parental feelings. International Journal of Psychology, Vol. 47, Supplement 1, pp. 403, 2012.

[15] Padurina E. Understanding of the reasons of a condition of the child as an object of non-linear psychology. The $14^{\text {th }}$ European Congress of Psychology (Milan, Italy 7-10 july 2015), AbstractBook, Posters, pp. 778, 2015. 